Relations industrielles

Industrial Relations

\title{
Developing a Measure of Industrial Relations Climate
}

\section{Ali Dastmalchian, Raymond Adamson et Paul Blyton}

Volume 41, numéro 4, 1986

URI : https://id.erudit.org/iderudit/050265ar

DOI : https://doi.org/10.7202/050265ar

Aller au sommaire du numéro

Éditeur(s)

Département des relations industrielles de l'Université Laval

ISSN

0034-379X (imprimé)

1703-8138 (numérique)

Découvrir la revue

Citer cet article

Dastmalchian, A., Adamson, R. \& Blyton, P. (1986). Developing a Measure of Industrial Relations Climate. Relations industrielles / Industrial Relations, 41(4), 851-859. https://doi.org/10.7202/050265ar
Résumé de l'article

This study aims at devising a set of scales for measuring the climate of industrial and labour relations within organizations
Tous droits réservés @ C Département des relations industrielles de l'Universite Laval, 1986
Ce document est protégé par la loi sur le droit d'auteur. L’utilisation des services d'Érudit (y compris la reproduction) est assujettie à sa politique d'utilisation que vous pouvez consulter en ligne.

https://apropos.erudit.org/fr/usagers/politique-dutilisation/ 


\title{
Developing a Measure of Industrial Relations Climate
}

\author{
Ali Dastmalchian \\ Raymond Adamson \\ and \\ Paul Blyton
}

This study aims at devising a set of scales for measuring the climate of industrial and labour relations within organizations

In the field of organizational behaviour, the concept of climate has been variously employed by researchers in attempts to investigate ways in which different organization structures shape the pattern of behaviour within those organizations. Climate is used to refer to a set of variables representing the «norms, attitudes, feelings and behaviours prevalent at the workplace» (Nicholson, 1979, p. 21; see also Litwin and Stringer, 1968; and Payne and Pugh, 1976). Organizational climate has been interpreted as an «intervening» variable between structure and behaviour, affected on the one hand by the external and the structural features of the organization, and at the same time influencing the end results and the employee related performance of the organization (Pugh and Payne, 1977).

Whilst there have been several indications of the usefulness of the climate concept for understanding employee motivation, satisfaction, quality of work life and overall organizational effectiveness (see for example Jones and James, 1979; Payne and Pugh, 1976) most of the studies using climate have adopted a highly generalized approach without specifying, or relating it to any particular set of organizational activities. The generality of this approach, however, has been criticized. "Work settings have numerous climates», point out Schneider and Reichers (1983) and «to speak of organizational climate per se without attaching a referent is meaningless» (p. 21). Some efforts have already been made to use the climate concept in a more specific way; examples of these include Schneider et al's (1980) reference to a service climate and Zohar's (1980) notion of a safety climate. However, given the significance of labour and industrial relations within organizations, the more focussed concept of an industrial relations climate

- DASTMAlChIAN, Ali, Professor, Department of Industrial Relations and Organizational Behaviour, College of Commerce, University of Saskatchewan

ADAMSON, Raymond, Professor School of Business and Economics, Wilfrid Laurier University.

BLYTON, Paul, Professor, Department of Business and Economics, University of Wales Institute of Science and Technology, United Kingdom.

** This paper is part of a research project supported by SSHRC. Financial assistance of the British Council is gratefully acknowledged.

Relat. ind., vol. 41, no 4, 1986 @ PUL ISSN 0034-379 X 
would also appear to have considerable a priori utility. Indeed, in one of the few studies addressing this notion, Nicholson (1979) has pointed to the possibilities for industrial relations climate both to provide a «theoretical bridge» between the structural characteristics of organizations and outcomes such as the incidence of conflict, and also to act as a diagnostic tool evaluating elements of industrial relations and recommending changes in the industrial relations system (see also Warr et al, 1978).

This concept of an industrial relations climate is generally taken to refer to some characteristic atmosphere in the workplace which affects the relationships between employees (and their representatives) and management related matters. In the few sources which have discussed this concept recently, researchers have identified both attitudinal and behavioural elements as important components within the climate measure (Warr et al, 1978; Nicholson, 1979; Kelly and Nicholson, 1980; Dastmalchian et al, 1982; Gundz and Whitehead, 1981).

Yet to date relatively little progress has been made in refining and operationalising the industrial relations climate concept. This is indicative of a more general lack of cross-fertilization between the concepts used in organizational theory and behaviour and those employed in industrial relations. According to Lewin and Feuille (1983) this broadening of the traditional boundaries of industrial relations research is needed to improve our understanding of the dynamics of labour, unions and management relationships (see also Purcell, 1983). The present authors support this view; the development of a construct to tap various aspects of industrial relations climate is seen to be one way of usefully linking organizational and industrial relations research. The potential value of such a measure not only for comprehending labour-management relationships within an organization, but also for systematically comparing across different organizations was the impetus for the present study. The objective then was to establish an instrument which adequately tapped the various elements which comprise an industrial relations climate within organizations.

\section{PROCEDURE}

From a review of the literature on union-management relationships (including Brett, 1980; Dastmalchian et al., 1982; Martin, 1980; Biasatti and Martin, 1979; Martin and Biasatti, 1979), a number of possible industrial relations climate scales were indentified for investigation. These were: union-management cooperation; aggression; apathy; hostility; union support; joint-participation; trust; goal identification; fairness; and power balance. The first five dimensions were chosen based on Martin's (1976) taxonomy of union-management relationships, and further elaboration of these pertaining to the important elements in relationships between managements and unions (Martin and Biasatti, 1979). The work of the above authors was based on earlier research done by Derber et al. (1958, 1961) in which a conceptualization of union-management relationships and their determinants were developed and tested in a sample of organizations in Illinois. The remainder of the climate scales were selected based on the work of Brett (1980), Dastmalchian et al. (1982), and Nicholson (1979). 
Originally, fifty-five descriptive statements relating to the above scales were devised. Consideration of the face validity of the questions, their wording and clarity resulted in a total of forty questions which formed the preliminary questionnaire. This questionnaire was sent to a group of Canadian industrial relations managers, union representatives, and labour arbitrators in order to examine the relevance and the validity of the statements. This was sent to 340 potential respondents (150 managers, 150 union representatives, and 40 labour arbitrators). The first group was identified by personnel associations in three provinces as being specifically industrial and labour relations managers. The second group, the union representatives, was approached by (i) contacting fourteen unions in Saskatchewan, and (ii) randomly selecting one hundred and thirty-six union offices across four provinces from the Yellow Pages. The third group, the labour arbitrators, was approached using public records in Ontario. Of the 340 potential respondents, 29 could not be located, 41 were inappropriate (e.g. no involvement with unions, or not allowed to participate in surveys) and 12 were unuseable due to missing information. Therefore, the total number of questionnaires was 258 of which 161 completed and useable ones were received (91 IR managers, 55 union representatives and 15 arbitrators). The respondents were asked to rate the relevance of the statement to the practice of industrial relations in their experience using a 5-point scale. They were also asked to qualify their responses with descriptive comments. Based on these comments, minor changes in the wording of some of the questions were made and one statement was eliminated.

\section{ANALYSIS}

Initially the responses were examined using frequency analysis in order to identify the areas that were considered highly relevant, and those not relevant, by the respondents. Table 1 summarizes these by identifying the intent of the questions and the percentage of the respondents who considered them highly relevant or not relevant. Table 1 shows that fourteen areas dealing mostly with union-management cooperation, trust and joint problem solving are rated as highly important for understanding the climate of industrial relations. On the other hand, six issues including the lack of interest of membership, lack of communication between the bargaining parties, and the aggressiveness of the parties were considered as unimportant by our sample in understanding industrial relations climate.

The results were then analyzed, using the analysis of means and standard deviations, Pearson correlation, and coefficient alpha (Cronback, 1951). Consideration was given to the correlations among statements of each scale and, taking each scale as one variable, to the correlations between the scale and each of the items forming that scale. Because of the possible conceptual similarities between some scales (e.g. trust, goal identification and fairness) where a statement was found to have low correlation with other statements in the same scale, attempts were made to examine its relationships with others. Thus, among the remaining thirty-nine statements, some have been removed from their original scales and placed within more suitable categories. Furthermore, as a result of the above process, the ten scales originally chosen were reduced to nine by merging «trust» and «goal identification") categories. 
Table 1

Highly Relevant and Non-Relevant Issues in IR Climate $(\mathbf{N}=161)$

\section{Highly Relevant Elements}

1. Extent to which the parties keep their work

2. Fairness of employment conditions

3. Sincerity to solve common problems

4. Negotiations in an atmosphere of good faith

5. Existence of informal consultation

6. Speed of grievance settlement

7. Joint attempts to create a better place to work

8. Fairness of collective bargaining

9. Fairness in union-management dealings

10. Cooperating in settling disputes

11. Union's positive contribution to organization

12. Aggressiveness in negotiations

13. The parties' respect for one another's goals

14. Free exchange of information between the parties

\section{Not-Relevant Elements}

1. Lack of interest expressed by members

2. Extent of using threats or sanctions

3. Extent to which parties quibble over issues

4. Hostility of union-management relationship

5. Aggressiveness of parties in general

6. Lack of communication between parties

$\begin{array}{ccc}\begin{array}{c}\text { \% of } \\ \text { Respondents* }\end{array} & \begin{array}{c}\text { Mean } \\ \text { Score }\end{array} & \text { S.D. } \\ 83.9 & 4.19 & 1.13 \\ 74.9 & 3.73 & 0.92 \\ 71.5 & 3.70 & 1.23 \\ 70.2 & 3.78 & 1.23 \\ 70.2 & 3.61 & 1.22 \\ 68.6 & 3.66 & 1.26 \\ 66.4 & 3.64 & 1.38 \\ 66.3 & 3.64 & 1.14 \\ 66.0 & 3.51 & 1.14 \\ 65.4 & 3.54 & 1.17 \\ 63.4 & 3.55 & 1.25 \\ 61.6 & 3.37 & 1.14 \\ 60.8 & 3.46 & 1.32 \\ & & \\ 60.3 & 3.34 & 1.23\end{array}$

$\begin{array}{lll}70.0 & 2.10 & 1.30 \\ 69.6 & 2.10 & 1.30 \\ 69.0 & 2.25 & 1.30 \\ 69.0 & 2.20 & 1.42 \\ 65.0 & 2.31 & 1.29 \\ 60.8 & 2.34 & 1.31\end{array}$

* For Highly Relevant Elements the percentage of respondents rating each item 4 or 5, and for Non-Relevant 2 or 1 , were considered. An issue is considered relevant or not relevant when $60 \%$ or more of the sample considered there as such.

Table 2 shows the nine industrial relations climate scales, number of items for each, means and standard deviations, and the reliability estimates both for the initial and the revised scales. The initial analysis indicated that the internal consistency reliability of scales such as power balance, union support and apathy were comparatively weak. This, as well as consideration of the correlations between items and other scales, led to the first revision of the climate scales, as shown in Table 1. At this stage, the total number of items for each scale. Examination of the reliability coefficients and corrected item-total correlations ${ }^{1}$, and the relationships among the nine scales, led to the rejection of two scales on grounds of low internal consistency. These were power balance and union support. However, some of the items from these two elements were retained. Further, the remaining seven categories were regrouped to form six final industrial relations climate

1 The reliability coefficient used is Cronbach's Alpha (Cronbach, 1951); and the corrected item-total correlation is the average of the correlations of each item with the sum of the remaining items forming each scale. 
Table 2

Initial IR Climate Scales

Revised Scales, their Means, Standard Deviations and Reliability Estimates

$(\mathbf{N}=16)$

Initial

First Revision

\begin{tabular}{|c|c|c|c|c|c|c|c|c|}
\hline & \multicolumn{4}{|c|}{ Initial } & \multicolumn{4}{|c|}{ First Revision } \\
\hline IR Climates Scales & $\begin{array}{l}\text { No. of } \\
\text { Items }\end{array}$ & $\begin{array}{l}\text { Mean } \\
\text { (s.d.) }\end{array}$ & $\alpha$ & $\begin{array}{l}\text { Mean } \\
\text { Corrected } \\
\text { Item- } \\
\text { Total } \\
\text { Corr. }\end{array}$ & $\begin{array}{l}\text { No. of } \\
\text { Items }\end{array}$ & $\begin{array}{l}\text { Mean } \\
(s . d .)\end{array}$ & $\alpha$ & $\begin{array}{l}\text { Mean } \\
\text { Corrected } \\
\text { Item- } \\
\text { Total } \\
\text { Corr. }\end{array}$ \\
\hline $\begin{array}{l}\text { 1. Union-Management } \\
\text { Cooperation }\end{array}$ & 5 & $\begin{array}{l}17.63 \\
(5.28)\end{array}$ & .883 & .724 & 5 & $\begin{array}{l}17.63 \\
(5.28)\end{array}$ & .883 & .724 \\
\hline 2. Aggression & 5 & $\begin{array}{l}13.53 \\
(4.61)\end{array}$ & .739 & .507 & 一 & - & - & - \\
\hline 3. Apathy & 3 & $\begin{array}{l}7.48 \\
(2.99)\end{array}$ & .630 & .444 & 3 & $\begin{array}{l}7.41 \\
(2.74)\end{array}$ & .652 & .453 \\
\hline 4. Hostility & 4 & $\begin{array}{c}9.33 \\
(4.62)\end{array}$ & .873 & .729 & 5 & $\begin{array}{l}14.28 \\
(4.80)\end{array}$ & .762 & .532 \\
\hline 5. Union Support & 5 & $\begin{array}{l}16.23 \\
(3.88)\end{array}$ & .604 & .418 & 4 & $\begin{array}{l}13.02 \\
(3.40)\end{array}$ & .608 & .413 \\
\hline 6. Joint-Participation & 4 & $\begin{array}{l}11.47 \\
(3.79)\end{array}$ & .682 & .498 & 3 & $\begin{array}{c}9.04 \\
(3.58)\end{array}$ & .866 & .746 \\
\hline 7. Trust/Goal Identification & 7 & $\begin{array}{l}23.99 \\
(5.61)\end{array}$ & .754 & .501 & 6 & $\begin{array}{l}21.41 \\
(5.80)\end{array}$ & .867 & .664 \\
\hline 8. Fairness & 3 & $\begin{array}{l}10.86 \\
(2.57)\end{array}$ & .731 & .561 & 4 & $\begin{array}{l}14.23 \\
(3.33)\end{array}$ & .753 & .555 \\
\hline 9. Power Balance & 3 & $\begin{array}{c}8.80 \\
(2.55)\end{array}$ & .474 & .298 & 3 & $\begin{array}{l}9.25 \\
(2.63)\end{array}$ & .511 & .328 \\
\hline Total Items: & 39 & & & & 33 & & & \\
\hline
\end{tabular}

scales. That is, aggression/hostility, goal identification/respect (i.e. mutual regard), and trust/fairness formed three new elements; joint-participation, quiescence and cooperation remained as scales with some alterations in their constituent items. The six final scales, number of items for each, sample items, and their reliability indicators are shown in Table 3.

This final version of the instrument measuring industrial relations climate represents six scales that have acceptable internal consistency reliability. Consideration of the relationships among these six elements also confirms that these elements constitute reasonably independent dimensions $^{2}$. For example, elements such as cooperation and trust/fairness, while positively correlated with each other, have negative relationships with hostility and apathy. It should be noted that since the respondents were asked to indicate the relevance and importance of the items for the practice of

2 The complete list of the questionnaire items for the six IR climate scales and their means and standard deviations, as well as the correlations among the scales are contained in a technical appendix, available upon request from the authors. 


\section{Table 3}

Final IR Climate Scales, their Sample Items, and Reliability Estimates $(\mathbf{N}=\mathbf{1 6 1})$

\begin{tabular}{|c|c|c|c|c|}
\hline Climate Scales & $\begin{array}{l}\text { No. of } \\
\text { Items }\end{array}$ & Sample Items & $\alpha$ & $\begin{array}{c}\text { Mean } \\
\text { Corrected } \\
\text { Item- } \\
\text { Total } \\
\text { Corr. }\end{array}$ \\
\hline $\begin{array}{l}\text { 1. Union-Management } \\
\text { Cooperation }\end{array}$ & 6 & $\begin{array}{l}\text { Union and management } \\
\text { work together to make } \\
\text { this organization a } \\
\text { better place to work }\end{array}$ & .765 & .575 \\
\hline 2. Mutual Regard & 3 & $\begin{array}{l}\text { Union and management } \\
\text { have respect for each } \\
\text { other's goals }\end{array}$ & .808 & .652 \\
\hline 3. Apathy & 4 & $\begin{array}{l}\text { Employees here rarely } \\
\text { express interest in the } \\
\text { outcomes of } \\
\text { negotiations }\end{array}$ & .722 & .501 \\
\hline 4. Joint-Participation & 3 & $\begin{array}{l}\text { In this organization } \\
\text { joint union- } \\
\text { management } \\
\text { committees achieve } \\
\text { definite results }\end{array}$ & .867 & .663 \\
\hline 5. Trust/Fairness & 5 & $\begin{array}{l}\text { The parties in this } \\
\text { organization keep their } \\
\text { word }\end{array}$ & .810 & .602 \\
\hline 6. Hostility/Aggression & 5 & $\begin{array}{l}\text { The parties regularly } \\
\text { quibble over minor } \\
\text { issues }\end{array}$ & .861 & .679 \\
\hline
\end{tabular}

Total Items

industrial relations, and not how they would characterize the climate in their respective organizations, some of the correlations were not as strong as one would expect. These six scales were then factor analyzed. Factor analysis was performed as a confirmatory technique to ensure that the scales are reasonably independent from each other. It produced two factors accounting for over $80 \%$ of the variance of the six scales. Unionmanagement cooperation, mutual regard, joint-participation, and trust and fairness significantly loadings under factor 1 , and hostility and apathy on factor 2. Therefore, these results show that the final six elements measuring industrial relations climate are reasonably valid and reliable and that they depict important dimensions of the industrial relations setting. 
Further analysis of the data revealed some noteworthy results in relation to the differences in the opinions of the industrial relations managers and the union representatives ${ }^{3}$. Table 4 shows one-way analysis of variance of mean scores for the above two groups of respondents.

Table 4

Comparison of the Opinions of Union and Management on IR Climate Scales

\begin{tabular}{lcccc} 
& \multicolumn{3}{c}{$\begin{array}{c}\text { Union } \\
\text { Represen- } \\
\text { tatives } \\
(N=55)\end{array}$} & $t$ value \\
IR Climate Scales & $\begin{array}{c}\text { Overall } \\
(N=161)\end{array}$ & $\begin{array}{c}\text { Managers } \\
(N=91)\end{array}$ & 15.96 & $8.05^{\mathrm{a}}$ \\
1. Union-Management Cooperation & 20.17 & 22.53 & $(5.29)$ & \\
& $(5.35)$ & $(4.19)$ & 16.72 & $5.64^{\mathrm{a}}$ \\
2. Mutual Regard & 13.20 & 14.35 & $(4.17)$ & \\
& $(3.93)$ & $(3.31)$ & 13.02 & 1.74 \\
3. Apathy & 13.04 & 11.86 & $(3.63)$ & \\
& $(4.21)$ & $(3.66)$ & 11.11 & $3.71^{\mathrm{a}}$ \\
4. Joint-Participation & 11.45 & 13.65 & $(3.50)$ & \\
& $(3.85)$ & $(3.78)$ & 15.90 & $6.45^{\mathrm{a}}$ \\
5. Trust/Fairness & 18.85 & 20.21 & $(5.04)$ & \\
& $(4.24)$ & $(2.82)$ & 13.39 & $5.34^{\mathrm{a}}$ \\
6. Hostility/Aggression & 11.30 & 9.03 & $(4.83)$ &
\end{tabular}

Mean scores, and Standard deviations (in brackets) are reported.

${ }^{a} t$ value is significant at .001 level (two tailed)

Table 4 shows that in the case of five of the industrial relations climate scales, there are significant differences in the ways in which the two groups perceived their importance and the relevance. Union representatives attached less importance to cooperation, respect/goal identification, jointparticipation, and trust/fairness compared with industrial relations managers. Industrial relations managers, on the other hand, felt that hostility/aggression as a dimension of climate has less importance or relevance compared with their union counterparts. Although the observed differences between managers and union representatives are not in some ways surprising, the consistency of their responses across different climate scales is quite interesting and indeed significant.

\section{SUMMARY AND DISCUSSION}

This paper has reported a preliminary study aimed at developing a set of scales to measure the climate of labour and industrial relations climate in organizations. Based on a review of the literature and by using data from a

3 Due to the comparatively low number of arbitrators in the sample, their responses were excluded from this analysis. 
sample of key actors involved in the practice of industrial relations, twentysix statements measuring six industrial relations climate scales have been devised. The validity and internal consistency reliability of these climate scales have been tested and established, and the differences that exist in perceptions of two groups of industrial relations actors have been highlighted.

These differences suggest the utility of exploring in more detail the composition of industrial and labour relations climate and the kinds of factors which affect and shape their development (Dastmalchian and Adamson, 1984). The present study has usefully begun this process and it is now the authors' intention to use this construct of industrial relations climate in organizational research. For example, the authors have employed the present climate construct in an in-depth study of two organizations in Canada. The results of this analysis has shown that the differences in the kinds of industrial relations climates both within each organization (i.e. departmental or bargaining unit variations) and between the two organizations can be attributed to factors such as organizational and departmental structures (e.g. decision-making centralization), industrial relations structure (e.g. bargaining structure and history or nature of unionization), and context or environment (e.g. size or the conditions of the labour market). Furthermore, the authors are involved in a more ambitious program of research in which the nature and the determinants of industrial relations climate will be examined within the cultural contexts of Canada and Britain. The results will hopefully be a greater theoretical understanding for how different elements of industrial relations interact, how these are shaped by various external influences (culture, economic and political environments, corporate structure, technology, etc.) and how the industrial relations climate impacts upon broader organizational processes.

\section{REFERENCES}

BIASATTI, L.L. and J.E. MARTIN, «A Measure of the Quality of UnionManagement Relationships», Journal of Applied Psychology, 64, 4, 1979, pp. 387-390.

BRETT, J.M., «Behavioural Research on Unions and Union-Management Systems", in B.M. Staw and L.L. Cummings (eds.), Research in Organizational Behaviour, Vol. 2, 1980, pp. 177-213.

CRONBACH, L.J., "Coefficient Alpha and the Internal Structure of Tests", Psychometrika, 16, 1951, pp. 297-334.

DERBER, M., W.E. CHALMERS, and M.T. EDELMAN, «Assessing UnionManagement Relationships», Quarterly Journal of Economics and Business, 1, 4, 1961, pp. 27-40.

DERBER, M., W.E. CHALMERS, and R. STAGNER, «Environmental Variables and Union-Management Accommodation», Industrial and Labor Relations Review, 11, 1958, pp. 413-428.

DASTMALCHIAN, A., and R. ADAMSON, «Organizational Climate and Labour-Management Relationships: Exploring the Concept of Industrial Relations Climate», in Organizational Behaviour, Vol. 5, H. Abravanel (ed.), Administrative Sciences Association of Canada, 1984, pp. 53-60. 
DASTMALCHIAN, A., P. BLYTON, and R. ABDOLLAHIAN, «Industrial Relations Climate and Company Effectiveness», Personnel Review, 11, 1, 1982, pp. 35-39.

GANDZ, J. and J.D. WHITEHEAD, «The Relationship Between Industrial Relations Climate and Grievance Initiation and Resolution", IRRA 34th Annual Proceedings, 1981, pp. 320-328.

JONES, A.P., and L.R. JAMES, «Organizational Climate: A Review of Theory and Research», Psychological Bulletin, 81, 1974, pp. 1096-1112.

KELLY, J.E., and N. NICHOLSON, "The Causation of Strikes: Review of Theoretical Approaches and Potential Contribution of Social Psychology», Human Relations, 33, 12, 1980, pp. 853-883.

LEWIN, D., and P. FEUILLE, «Behavioural Research in Industrial Relations», Industrial and Labour Relations Review, 36, 3, 1983, pp. 341-360.

LITWIN, G., and R. STRINGER, Motivation and Organizational Climate, Harvard Univ. Press, Mass., 1968.

MARTIN, J.E., «Federal Union-Management Relations: A Longitudinal Study», Public Administration Review, Sept-Oct., 1980, pp. 434-442.

"Union-Management Problems in the Federal Government: An Exploratory Analysis», Public Personnel Management, 5, 1976, pp. 353-362.

MARTIN, J.E., and L.L. BIASATTI, «A Hierarchy of Important Elements in Union-Management Relations», Journal of Management, 5, 1979, pp. 229-240.

NICHOLSON, N., «Industrial Relations Climate: A Case Study Approach», Personnel Review, 8, 3, 1979, pp. 20-25.

PAYNE, R., and D.S. PUGH, «Organizational Structure and Climate», in M.D. Dunnette (ed.), Handbook of Industrial and Organizational Psychology, Chicago, Rand McNally, 1976, pp. 1125-1173.

PUGH, D.S., and R. PAYNE, Organizational Behaviour in its Context: The Aston Programme III, Hants., Gower, 1977.

PURCELL, J., «The Management of Industrial Relations in the Modern Corporation: Agenda for Research», British Journal of Industrial Relations, 21, 1, 1983, pp. $1-16$.

SCHNEIDER, B., and A.E. REICHERS, «On Etiology of Climates», Personnel Psychology, 36, 1983, pp. 19-39.

SCHNEIDER, B, J.J. PARKINGTON, and V.M. BUXTON, «Employee and Customer Perception of Service in Banks», Administrative Science Quarterly, 25, 1980, pp. 252-267.

STRAUSS, G., and P. FEUILLE, «IR Research: A Critical Analysis», Industrial Relations, 17, 3, 1978, 259-277.

WARR, P.B., S. FINEMAN, N. NICHOLSON, and R. PAYNE, Developing Employee Relations, Hants., Gower, 1978.

ZOCHAR, D., "Safety Climate in Industrial Organizations: Theoretical and Applied Implications», Journal of Applied Psychology, 65, 1980, pp. 96-102. 